\title{
Dampak E-Servive Quality Terhadap E-Satisfaction Serta Implikasinya Pada Online Repurchase B2C Shopee.com
}

\author{
Raras Ivastya ${ }^{1^{*}}$, Zaenal Fanani ${ }^{2}$ \\ ${ }^{1,2}$ Fakultas Ekonomi dan Bisnis Universitas Airlangga Surabaya \\ ${ }^{1}$ raras.ivastya-2017@feb.unair.ac.id, ${ }^{2}$ fanani@feb.unair.ac.id \\ *Penulis Korespondensi
}

\begin{abstract}
Internet services that were introduced in 1993 have an impact on behavior change and the ways of consumer decisions making. The emergence of various developments in information technology, connectivity and smartphones are also slowly able to change the way of consumers for meet the needs of a product or service. This research was conducted for intention to examine the effect of e-service quality on e-satisfaction and implications on B2C consumer repurchase online. Data was taken using an online questionnaire and distributed to B2C consumers with the last amount of data collected as many as 312 questionnaires and then be analyzed using the partial least square method. The results of the analysis show that e-service quality provides a significant positive effect on e-satisfaction and online repurchase for B2C consumers. In other results show e-satisfaction has a significant effect on online repurchase and is able to be a partial mediator of the relationship of e-service quality with online repurchase of B2C consumers.
\end{abstract}

Keywords: B2C; E-Service Quality; E-Satisfaction; Online Repurchase

\begin{abstract}
Abstrak
Layanan internet yang diperkenalkan pada tahun 1993 berdampak pada perubahan perilaku dan cara pengambilan keputusan konsumen. Munculnya berbagai perkembangan teknologi informasi, konektivitas dan smartphone juga perlahan mampu mengubah cara konsumen memenuhi kebutuhan suatu produk atau layanan. Penelitian ini dilakukan bertujuan untuk menguji pengaruh kualitas layanan elektronik terhadap kepuasan elektronik dan implikasinya terhadap pembelian kembali konsumen B2C secara online. Pengambilan data menggunakan kuisioner online dan disebarkan kepada konsumen B2C dengan jumlah data terakhir yang terkumpul sebanyak 312 kuisioner kemudian dianalisis menggunakan metode partial least square. Hasil analisis menunjukkan bahwa kualitas layanan elektronik memberikan pengaruh positif yang signifikan terhadap kepuasan elektronik dan pembelian kembali secara online untuk konsumen B2C. Hasil lain menunjukkan kepuasan elektronik berpengaruh signifikan terhadap pembelian kembali online dan mampu menjadi mediator parsial hubungan kualitas layanan elektronik dengan pembelian kembali online konsumen B2C.
\end{abstract}

Kata kunci: B2C; E-Service Quality; E-Satisfaction; Online Repurchase

\section{Cara Mengutip:}

Ivastya, R., Fanani, Z. (2020). Dampak E-Servive Quality Terhadap E-Satisfaction Serta Implikasinya Pada Online Repurchase B2C Shopee.com. Esensi: Jurnal Bisnis dan Manajemen. Vol. 10 (1) : 109-118. 


\section{PENDAHULUAN}

Sejak adanya komersialisasi internet pada tahun 1993 secara bertahap merubah perilaku dan cara pengambilan keputusan. Di samping itu, munculnya perkembangan teknologi informasi, konektivitas serta platform smartphone sedikit banyak juga mampu mengubah cara-cara konsumen baik itu secara individu maupun berkelompok dalam upaya memenuhi segala kebutuhannya baik kebutuhan barang ataupun jasa. Di saat yang sama, adanya perkembangan teknologi tersebut ternyata memberikan dampak yang nyata bagi para produsen baik penyedia barang ataupun jasa dalam memperkenalkan dan menawarkan usahanya. Hasilnya sekarang banyak sekali ditemui berbagai produk dan layanan tersedia bagi konsumen melalui saluran online yang terus meningkat (Xu, Benbasat, \& Cenfetelli, 2013). Dengan adanya internet, konsumen dapat lebih mudah untuk mendapatkan suatu informasi yang berkualitas. Kualitas informasi merupakan persepsi pelanggan tentang kualitas informasi yang ditampilkan pada aplikasi e-commerce. Kualitas informasi terdiri dari dua jenis, yaitu kecukupan konten (reliabilitas, kecukupan, dan kelengkapan informasi yang diberikan) dan kegunaan konten (keinformatifan dan nilai informasi yang ditampilkan).

Perkembangan e-commerce di Indonesia dimulai pada tahun 1994 - 1999 (Kompas. com, 2017), bermula dari adanya website e-commerce pertama yaitu bhineka.com pada tahun 1996 yang kemudian terus mengalami perkembangan dengan munculnya situs-situs e-commerce lain, antara lain tokobagus.com, bukalapak.com dan lain-lain. Salah satu situs dari e-commerce yang sekarang sangat terkenal di Indonesia adalah shopee.com. Shopee adalah e-comemerce berbasis website dan aplikasi mobile yang masih tergolong baru, shopee banyak menghadirkan fitur dan penawaran yang menarik, salah satunya adalah gratis biaya kirim ke seluruh Indonesia. Di samping itu, sebagai platform e-commerce yang masih tergolong baru ternyata shoppe.com menduduki peringkat 3 besar e-commerce yang paling banyak dikunjungi oleh konsumen Indonesia di tahun 2019. Mengacu pada riset yang dilakukan oleh Indonesian Ecommerce Association (IdEA) dikemukakan bahwa shopee.com menduduki peringkat ketiga e-commerce dengan jumlah pengunjung sebanyak 476,5 juta kunjungan di bawah tokopedia.com serta bukalapak.com.

Seiring dengan perkembangan di bidang marketing e-commerce yang diikuti juga dengan peningkatan jumlah perusahaan yang bergerak dalam platform serupa, maka perusahaan khususnya shopee.com memerlukan pemahaman yang lebih detail mengenai perilaku dari konsumen dan calon konsumennya. Perilaku konsumen yang dimaksudkan dalam hal ini adalah bagaimana konsumen mempersepsikan dan mengevaluasi e-service quality pada suatu layanan e-commerce, sehingga pada akhirnya dapat menjadi hal yang sangat penting bagi perusahaan. Hal ini karena e-service quality yang baik dirasakan mampu meningkatkan potensi yang berguna untuk kepentingan manfaat strategis serta meningkatkan efisiensi operasional dan keuntungan dari perusahaan. Selanjutnya dengan e-service quality yang baik pula akan memberikan keuntungan pada perusahaan untuk menarik dan mempertahankan konsumennya, sehingga akan timbul loyalitas untuk tetap menggunakan layanan yang sama (Zeithaml, 2000).

E-service quality sangat penting untuk evaluasi dan penilai pelangggan dalam bisnis e-commerce. Perusahaan dapat meningkatkan mutu dan kualitas dengan adanya e-service quality karena memudahkan untuk mengevaluasi tingkat keberhasilan atau kegagalan 
perusahaan e berbasis internet. E-commerce dapat memudahkan pelanggan mengakses aplikasi seluler untuk memenuhi kebutuhan melalui aplikasi mobile dan kemudahan transaksi memiliki pengaruh signifikan pada tingkat e-service quality. Dengan kata lain, aplikasi seluler dianggap sebagai salah satu instrumen bisnis online untuk memberikan kualitas layanan elektronik kepada pelanggan salah satunya dengan belanja online. E-commerce menyediakan cara yang lebih baik dalam berbelanja, membeli, dan mengirimkan produk dan layanan. Menurut definisi ini, e-service quality merupakan faktor penting dalam menyediakan layanan pelanggan yang cukup untuk berbelanja dengan percaya diri dan nyaman, dan memiliki harapan pada pengiriman cepat dan layanan yang dapat diandalkan (Lee \& Lin, 2005; Piccoli, Brohman, Watson, \& Parasuraman, 2004; Zeithaml, Parasuraman, \& Malhotra, 2002). Zeithaml et al. (2002).

E-satisfaction merupakan pengukuran kepuasan pelanggan dalam suatu tingkatan yang dihasilkan oleh suatu layanan (Oliver, 1997). Kepuasan pelanggan merupakan faktor penting yang bertujuan untuk memahami kebutuhan dan keinginan pelanggan agar terpenuhi. Pelanggan merasa tidak puas apabila kinerja layanan tidak memenuhi keinginan (Churchill, 1991). Tingkat kepuasan dan ketidakpuasan dapat mempengaruhi niat untuk pembelian kembali (Cronin, Brady, \& Hult, 2000). Kepuasan pelanggan adalah factor penting untuk memahami dan mengevaluasi keinginan pelanggan. Dengan adanya pembelian kembali dapat meningkatkan pangsa pasar yang dihasilkan dari pembelian berulang (Kotler, 2000).

Online Repurchase merupakan suatu tindakan pelanggan untuk menggunakan atau membeli produk kembali. Pelanggan yang telah membeli barang tersebut memiliki potensi untuk mengulangi pembelian kembali yaitu mengkonsumsi produk sama dari penjual yang sama. Dapat dikatakan pembelian kembali merupakan tindakan pembelian kembali yang merupakan keputusan pelanggan untuk mengkonsumsi produk secara berulang (Hume, Mort, \& Winzar, 2007; Puon \& Dat, 2017).

Berbagai penelitian yang terkait dengan e-commerce menyimpulkan bahwa e-service quality berpengaruh positif terhadap online repurchase, kepuasan serta loyalitas konsumen (Liu, 2012). Hal ini sama dengan penelitian yang dilakukan oleh Khalifa \& Liu (2007) menyebutkan bahwa adanya e-satisfaction konsumen mampu menjadi pemediasi pada hubungan antara pengalaman dan kebiasaaan belanja secara online dengan online repurchase. Sementara itu, Sharma (2015) menyimpulkan bahwa e-service quality berpengaruh positif terhadap satisfaction, dan ditambahkan dalam penelitian lain bahwa service quality memiliki pengaruh positif terhadap repurchase intentions secara langsung dan tidak langsung melalui kepuasan (Lin \& Lekhawipat, 2014; Saleem et al., 2017).

Penelitian ini bermaksud untuk menguji pengaruh antara e-service quality terhadap e-satisfaction serta online repurchase untuk konsumen B2C yang menggunakan platform e-commerce shopee.com. Hal ini menjadi menarik untuk dikaji mengingat kapasitas dari shoppe.com dibawah naungan PT. Shopee Internasional Indonesia sebagai big three layanan e-commerce yang banyak dikunjungi oleh konsumen di Indonesia pada tahun 2019. Selain itu, sebagai salah satu layanan baru e-commerce di Indonesia penelitian dengan obyek Shopee. com layak dijadikan pertimbangan sebagai tambahan petunjuk dan informasi bagi konsumen e-commerce serta sebagai bahwa evaluasi pihak pengembang dan manajemen shopee.com dalam mengembangkan layanan layanan yang lebih berkualitas. Dengan demikian melalui 
studi perilaku konsumen shopee.com ini nantinya dapat dihasilkan layanan e-commerce yang mampu memenuhi kebutuhan para konsumen pada masa-masa mendatang.

Di dalam dunia pemasaran, prinsip kualitas dikonseptualisasikan sebagai "persepsi kualitas", yang tergantung pada penilaian dari konsumen. Adanya layanan dalam perspektif yang baik dan buruk dapat dijadikan konstruk individual untuk prediktor niat pembelian kembali (Saleem et al, 2017). Penelitian yang dilakukan oleh Namukasa (2013) dan Hussain (2016) menyimpulkan bahwa keberadaan dari e-service quality, e-satisfaction dan repurchase intention merupakan keterkaitan yang mengarahkan hubungan positif. Berdasarkan uraian tersebut, dapat disusun hipotesis sebagai berikut:

$\mathrm{H}_{1}$ : E-service quality berpengaruh positif terhadap online repurchase

Li \& Suomi (2007) menyatakan bahwa service quality memiliki dampak yang kuat pada kepuasan konsumen dan kinerja perusahaan. Kepuasan konsumen digambarkan sebagai evaluasi positif atas kinerja perusahaan berdasarkan pada pengalaman sebelumnya yang dirasakan, termasuk service quality (Fornell, 1992). Chen et al. (2012) dalam ulasannya juga mengemukakan bahwa dalam lingkup toko online, kepuasan konsumen merupakan salah satu kunci yang penting berkaitan dengan peningkatan profitabilitas, tingkat retensi konsumen, serta pertumbuhan jangka panjang dari toko online. Berdasarkan uraian keterkaitan tersebut, maka dapat disusun hipotesis dalam penelitian sebagai berikut:

$\mathrm{H}_{2}$ : E-service quality berpengaruh positif terhadap e-satisfaction

Konsumen yang tidak puas akan mencari solusi untuk berpindah kepada toko yang lain demi mendapatkan kepuasan. Artinya terdapat pengaruh positif antara e-satisfaction terhadap online repurchase. Sehingga apabila e-satisfaction terhadap online repurchase mengalami peningkatan, maka akan meningkatkan tingkat keinginan untuk pembelian kembali. Konsumen yang merasakan tingkat kepuasan lebih besar mungkin untuk membeli kembali lebih banyak di masa depan daripada konsumen yang tidak puas (Gupta dan Kim, 2010 ; Sanchez-Garcia et al., 2012). Sementara itu, Lin dan Lekhawipat (2014) dalam hasil penelitiannya menyampaikan e-satisfaction memiliki pengaruh secara langsung dan tidak langsung pada online repurchase. Dari uraian di atas, maka dapat disusun hipotesis:

$\mathrm{H}_{3}$ : E-satisfaction berpengaruh positif terhadap online repurchase

Khalifa \& Liu (2007) menyebutkan bahwa adanya e-satisfaction konsumen mampu menjadi pemediasi pada hubungan antara pengalaman dan kebiasaaan belanja secara online dengan online repurchase. Ketika konsumen merasa puas terhadap pelayanan yang diberikan penjual, maka akan terbentuk keinginan untuk melakukan pembelian kembali, semakin tinggi kepuasan konsumen akan berimplikasi pada pembelian kembali. Kepuasan sebagai salah satu bentuk evaluasi yang dilakukan konsumen dalam menggunakan layanan jasa memiliki peran penting dalam menentukan perilaku konsumen pada masa masa mendatang. Apabila konsumen yang merasakan tingkat kepuasan lebih besar mungkin untuk membeli kembali lebih banyak di masa depan daripada konsumen yang tidak puas (Gupta dan Kim, 2010 ; Sanchez-Garcia et al., 2012). Sementara itu, Lin dan Lekhawipat (2014) dalam hasil penelitiannya menyampaikan e-satisfaction memiliki pengaruh secara langsung dan tidak langsung pada online repurchase.. Dari uraian di atas, maka dapat disusun hipotesis: $\mathrm{H}_{4}$ : E-satisfaction memediasi hubungan antara e-service quality dengan online repurchase 


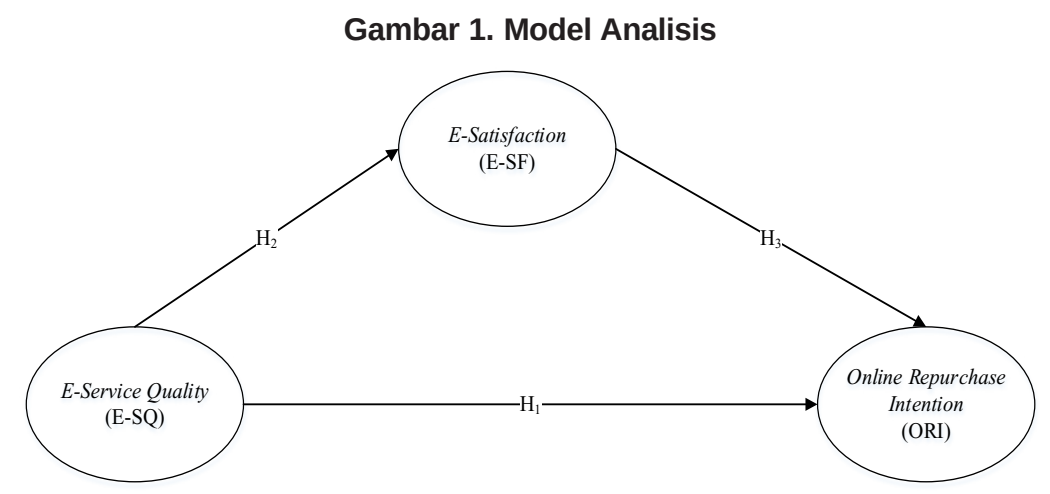

\section{METODE}

Penelitian ini dilakukan secara kuantitatif dengan mengambil sampel yang disebarkan secara online dengan metode random sampling yaitu konsumen dari shopee.com berjumlah 312 orang. Pengukuran variabel penelitian disusun atas item-item pertanyaan dari teori terkait melalui jurnal terdahulu. Variabel $e$-service quality disusun atas indikator efficiency, fullfillment, system availability, privacy, responsiveness, compensation, contact (Zeithmal et al., 2009; Zehir \& Narcikara, 2016). Variabel e-satisfaction diukur melalui indikator kelengkapan layanan serta rekomendasi (Liao et al., 2017), sedangkan untuk variabel online repurchase diukur dengan indikator minat pembelian ulang serta ketidakkahawatiran melakukan pembelian ulang di masa depan (Sullivan \& Kim, 2018). Variabel penelitian yang diukur melalui kuesioner dilakukan analisis data dengan menggunakan metode partial least square dengan perangkat lunak Smart PLS 2.0 melalui evaluasi outer model serta inner model. Ketetapan signifikansi pengaruh antar variabel dinilai dengan nilai T-Statistics yang lebih besar dari 1,96 (Jogiyanto \& Abdillah, 2009).

\section{HASIL DAN PEMBAHASAN}

Jumlah responden sebagai sampel penelitian dengan jumlah sebanyak 312 memiliki profil serta tanggapan penilaian atas variabel-variabel penelitian yang terangkum pada Tabel 2. Sampel penelitian sebagian besar adalah seorang perempuan sebanyak 208 orang (66,7\%) yang berusia antara 20 hingga 25 tahun dengan jumlah 136 orang (43,6\%). Profil berpendidikan responden penelitian sebagian besar adalah Strata 1/S1 sebanyak 238 orang (76,3\%) yang sebagian besar berprofesi sebagai karyawan swasta dengan jumlah sebanyak 152 orang $(48,7 \%)$ dengan tingkat penghasilan per bulan Rp 5 juta hingga Rp. 10 juta sebanyak 164 orang (52,6\%). Profil berikutnya dikemukakan bahwa pendorong yang mendasari dalam aktifitas belanja online oleh konsumen sebagian besar karena adanya informasi dari media iklan $(61,9 \%)$ dan rekomendasi teman $(51,6 \%)$.

Uraian selanjutnya mengenai tanggapan responden atas masing-masing variabel penelitian kesemuanya termasuk dalam kategori sangat baik dengan nilai tanggapan masing masing mean adalah e-service quality sebesar 4,530, variabel e-satisfaction sebesar 4,526 dan online repurchase sebesar 4,567. Berdasarkan pada hasil di atas, dapat dijelaskan bahwa responden menilai bahwa e-service quality yang diberikan oleh Shopee.com kepada para konsumennya sudah bagus sehingga dapat meningkatkan kepuasan dan niat konsumen untuk melakukan pembelian berulang di Shopee.com. 
Tabel 2. Profil dan Mean Tanggapan Responden

\begin{tabular}{|c|c|c|}
\hline Profil & $f$ & $\%$ \\
\hline \multicolumn{3}{|l|}{ Jenis Kelamin } \\
\hline Laki-Laki & 104 & 33,3 \\
\hline Perempuan & 208 & 66,7 \\
\hline \multicolumn{3}{|l|}{ Usia } \\
\hline$<20$ tahun & 12 & 3,8 \\
\hline $20-25$ tahun & 136 & 43,6 \\
\hline $26-30$ tahun & 107 & 34,3 \\
\hline$>30$ tahun & 57 & 18,3 \\
\hline \multicolumn{3}{|l|}{ Pendidikan } \\
\hline$<\mathrm{D} 1$ & 13 & 4,2 \\
\hline D3 & 35 & 11,2 \\
\hline $\mathrm{S} 1$ & 238 & 76,3 \\
\hline $\mathrm{S} 2$ & 26 & 8,3 \\
\hline \multicolumn{3}{|l|}{ Pekerjaan } \\
\hline Mahasiswa & 30 & 9,6 \\
\hline PNS & 34 & 10,9 \\
\hline Swasta & 152 & 48,7 \\
\hline Wiraswasta & 43 & 13,8 \\
\hline BUMN & 42 & 13,5 \\
\hline Tidak Bekerja & 11 & 3,5 \\
\hline \multicolumn{3}{|l|}{ Penghasilan per bulan } \\
\hline$<$ Rp. 3.000 .000 & 33 & 10,6 \\
\hline Rp. 3.000 .000 - Rp. 5.000 .000 & 70 & 22,4 \\
\hline Rp. 5.000.001 - Rp. 10.000 .000 & 164 & 52,6 \\
\hline > Rp. 10.000 .000 & 45 & 14,4 \\
\hline \multicolumn{3}{|l|}{ Pendorong dalam belanja online } \\
\hline Info media iklan & 193 & 61,9 \\
\hline Rekomendasi teman & 161 & 51,6 \\
\hline Variabel & \multicolumn{2}{|c|}{ Mean } \\
\hline E-service quality (E-SQ) & \multicolumn{2}{|c|}{4,530} \\
\hline E-satisfaction (E-SF) & \multicolumn{2}{|c|}{4,526} \\
\hline Online repurchase (ORI) & \multicolumn{2}{|c|}{4,567} \\
\hline
\end{tabular}

Data variabel penelitian yang telah memenuhi kriteria penelitian dengan kualitas baik dilakukan uji validitas dan reliabilitas, dan kemudian diestimasi hubungan kausalitasnya dalam model struktural dengan partial least square sebagai berikut:

\section{a. Evaluasi Outer Model}

Evaluasi outer model analisis partial least square dilakukan untuk pengujian validitas dan reliabilitas konstruk model struktural penelitian. Uji validitas terdiri atas pengujian indicator reliability, discriminant validity, dan convergent validity. Sementara itu, untuk pengujian reliabilitas digunakan internal consistency dengan kriteria cronbach alpha dan composite reliability. Hasil estimasi awal dari evaluasi outer model menunjukkan terdapat 1 indikator pada e-service quality (e-servqual $5=-0,128$ ) belum valid yang selanjutnya dilakukan reduksi indikator dan dilakukan proses running ulang dan hasilnya dirangkum 
pada Tabel 3. Tabel 3 menunjukkan bahwa nilai outer loading > 0,5 dengan T-Statistics > 1,96 serta nilai AVE > 0,5 yang berarti telah memenuhi asumsi indicator reliability dan covergent validity. Sementara itu, pada ukuran internal consistency diperoleh nilai composite reliability > 0,7 juga telah disimpulkan baik. Di samping itu, nilai Q Square semua variabel lebih besar dari 0 yang menunjukkan bahwa model struktural yang disusun telah mampu melakukan prediksi yang baik atau predictive relevance.

Tabel 3. Evaluasi Kriteria Indeks Kesesuaian Model Struktural

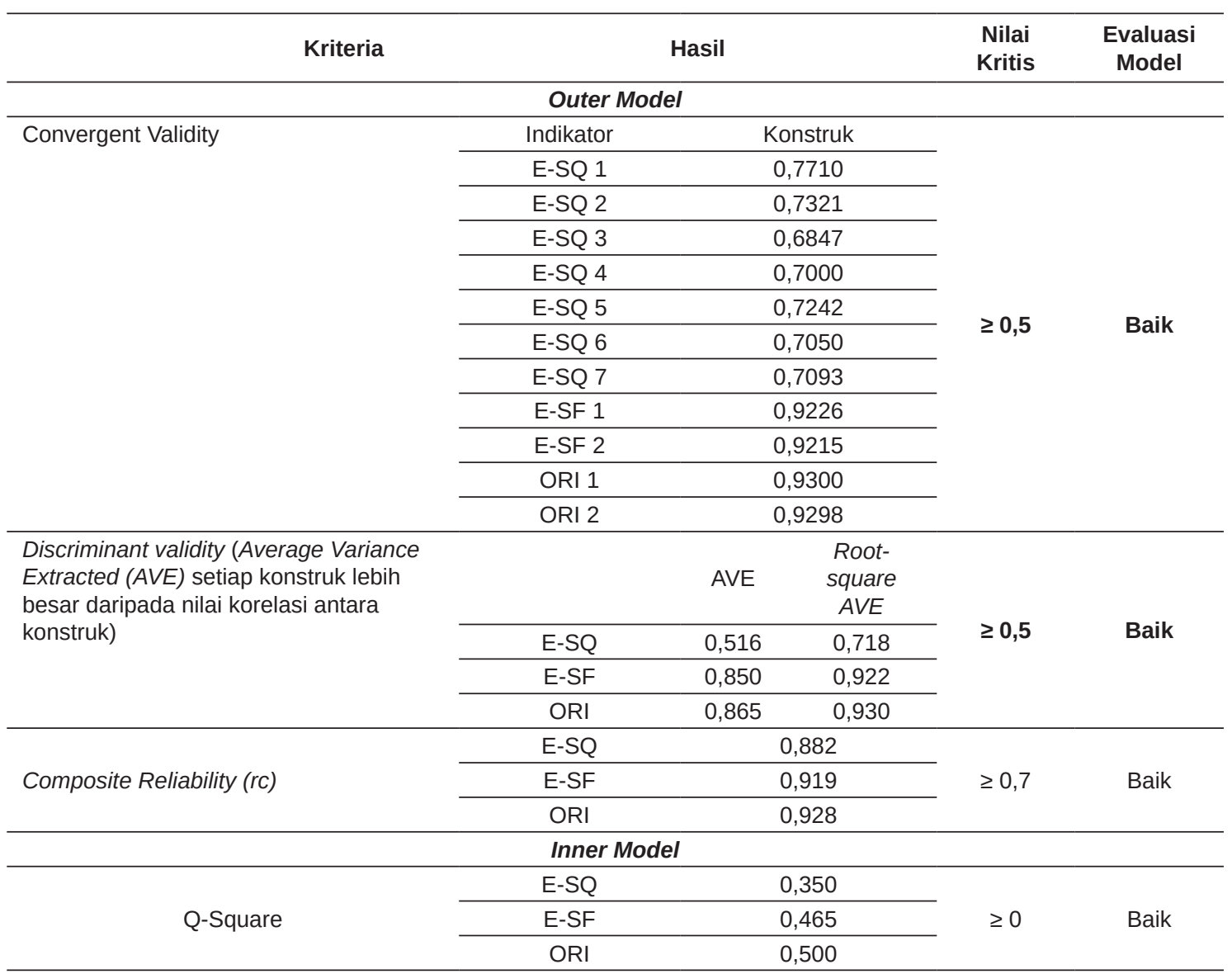

Sumber: Hasil olahan data primer (2013)

Gambar 2. Outer Model Estimate

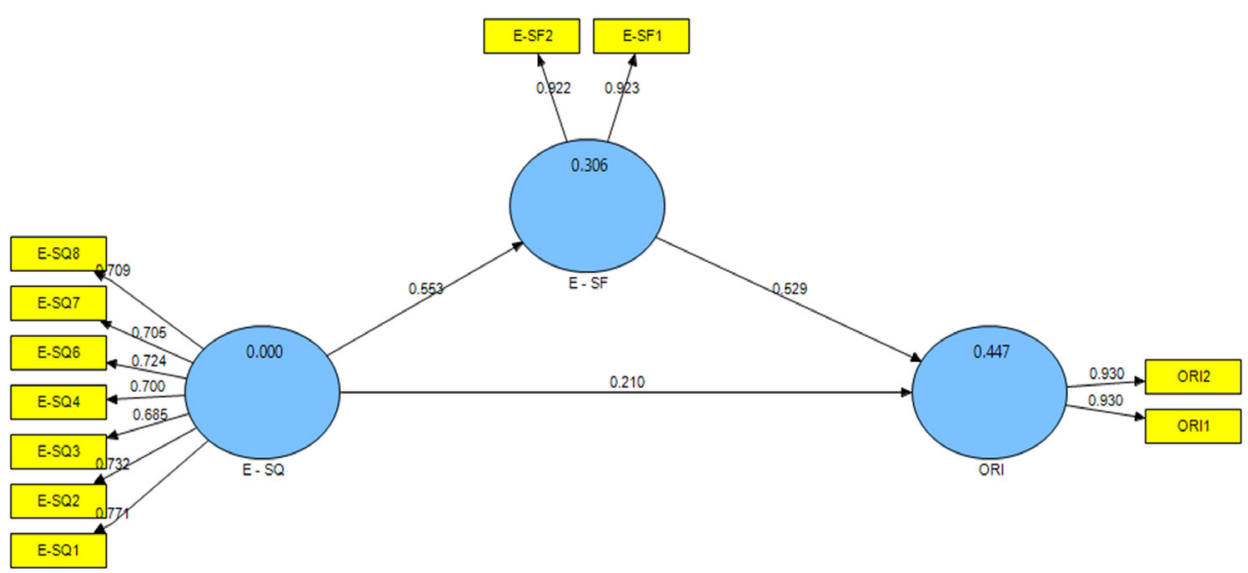




\section{b. Evaluasi Inner Model}

Hasil dari estimasi bootstrapping untuk inner model disajikan pada Gambar 2 sebagai berikut:

\section{Gambar 3. Inner Model With Bootstrapping}

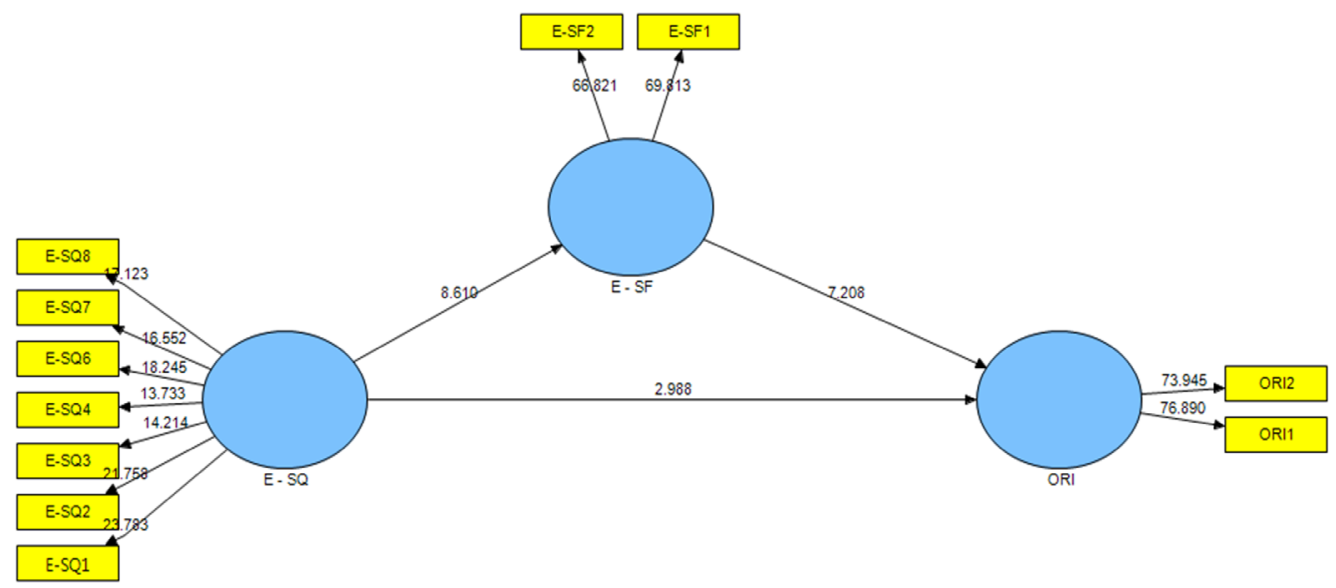

Sementara itu, untuk ringkasan hasil pada nilai inner weights untuk estimasi bootstrapping yang menunjukkan pengaruh suatu variabel terhadap variabel yang lainnya yang digunakan dalam pengujian hipotesis disajikan pada Tabel 4 sebagai berikut:

Tabel 4. Inner Weight dan Pengujian Hipotesis

\begin{tabular}{lcccccc}
\hline \multicolumn{1}{c}{ Jalur } & $\begin{array}{c}\text { Direct } \\
\text { Effect }\end{array}$ & $\mathbf{T}$ & $\mathbf{p}$ & $\begin{array}{c}\text { Indirect } \\
\text { Effect }\end{array}$ & T & p \\
\hline E-service quality $\rightarrow$ Online repurchase & 0,210 & 2,988 & 0,001 & 0,293 & 5,945 & 0,000 \\
E-service quality $\rightarrow$ E-satisfaction & 0,553 & 8,610 & 0,000 & & & \\
E-satisfaction $\rightarrow$ Online repurchase & 0,529 & 7,208 & 0,000 & & \\
\hline
\end{tabular}

Mengacu Tabel 4 dijelaskan bahwa terdapat pengaruh positif antara variabel $e$-service quality terhadap e-satisfaction $(\beta=0,553 \mathrm{p}=0,000)$ dan online repurchase $(\beta=0,210 \mathrm{p}=0,000)$ para konsumen dari shopee.com. Berdasarkan hasil tersebut maka H1 dan H2 penelitian dapat diterima secara statistik.

Hasil ini menegaskan penelitian yang dilakukan oleh Namukasa (2013) dan Hussain (2016) bahwa kesesuaian atas pelayanan memiliki hubungan dengan tingkat kepuasan dan niat konsumen untuk melakukan pembelian kembali.. Apabila ekspektasi konsumen atas pelayanan yang diberikan oleh penyedia jasa sudah bagus maka akan menimbulkan suatu kepuasan dan pada akhirnya akan mendorong niatnya untuk melakukan pembelian yang serupa. Dalam konteks online shopping, juga dapat diimplementasikan bahwa kesesuaian atas ekspektasi layanan sebagai pendorong penting niat pembelian kembali, sehingga menjadi sangat penting bagi penyedia jasa online untuk memahami harapan dan kebutuhan dari para konsumennya. Sementara pada penelitian oleh Bresolles et al. (2016) disebutkan bahwa e-service quality merupakan tipologi prediktif dari e-satisfaction dari para konsumen online. 
Tipologi dalam hal ini mengusulkan bahwa karena kepuasan yang diperoleh oleh para konsumen online tidak akan sama satu dengan lainnya pada waktu berinteraksi dengan sebuah situs belanja online maka ; Oleh karena itu, diperlukan memasukkan faktor heterogenitas konsumen, misalnya ketersediaan kategori-kategori produk layanan.

Hasil lainnya dikemukakan bahwa e-satisfaction memiliki pengaruh positif terhadap online repurchase $(\beta=0,529 \mathrm{p}=0,000)$, dengan demikian H3 dapat diterima secara statistik. Dalam hal ini kepuasan konsumen akan mempengaruhi keinginan untuk melakukan pembelian kembali. Apabila konsumen merasa tidak puas, mereka akan mencari penjual lain yang dapat memberikan kepuasan tersendiri. Sehingga dapat diketahui bahwa e-satisfaction berpengaruh positif terhadap online repurchase. Hasil ini sama dengan hasil penelitian oleh Khalifa \& Liu (2007) yang menyatakan bahwa pengaruh kepuasan terhadap niat pembelian kembali para pembeli online akan diperkuat dengan adanya faktor kebiasaan dan berpengalaman. Kondisi ini berarti konsumen yang cenderung memiliki kebiasaan belanja online akan melakukan pembelian kembali ketika merasakan suatu kepuasan. Hasil dari pengaruh mediasi antara e-service quality terhadap online repurchase dengan mediasi e-satisfaction menggunakan rumus Sobel test disimpulkan signifikan $(\beta=0,293 \mathrm{p}=0,000)$. Besar pengaruh langsung $\left(\beta_{\text {direct effect }}\right)$ sebesar 0,210 lebih kecil dibandingkan pengaruh tidak langsung $\left(\beta_{\text {indirect effect }}\right)$ sebesar 0,293, sehingga mediasi yang terjadi antar variabel dapat dibuktikan secara statistik dan bersifat partial mediation. Dengan demikian maka H4 dalam penelitian juga dapat diterima secara statistik.

\section{KESIMPULAN}

Berdasarkan atas hasil penelitian dapat disimpulkan bahwa e-service quality memiliki pengaruh secara langsung dan tidak langsung pada online repurchase konsumen shopee.com. Hasil lain didapatkan bahwa e-service quality juga berpengaruh positif terhadap e-satisfaction, sementara e-satisfaction memiliki pengaruh positif terhadap online repurchase. Kondisi ini menunjukkan bahwa terjadi mediasi secara parsial pada hubungan antara e-service quality terhadap online repurchase melalui variabel $e$-satisfaction pada konsumen yang menggunakan layanan jasa e-commerce shopee.com.

Penelitian menunjukkan bahwa dengan adanya pelayanan yang bagus, konsumen akan merasa puas dan melakukan pembelian kembali. Saat ini transaksi dapat dilakukan dengan mudah via internet, online repurchase merupakan topik penelitian yang menarik sebab sebagian besar masyarakat telah melakukan pembelian melalui online.

\section{DAFTAR PUSTAKA}

Chen, Z., Ling, K. C., Ying, G.X., \& Meng, T.C. (2012). Antecedents of online customer satisfaction in China. International Business Management, 6(2), 168-175.

Fornell, C. (1992). A National Customer Satisfaction Barometer The Swedish Experience. Journal of Marketing, 56, 6-21.

Gupta, S., \& Kim, H.W. (2010). Value-driven internet shopping: the mental accounting theory perspective. Psychology and Marketing, 27(1), 13-35.

Jogiyanto \& Abdillah., W. (2009). Partial Least Square (PLS) Alternatif SEM Dalam Penelitian Bisnis. Yogyakarta: Andi Offset. 
Khalifa, M., \& Liu, V. (2007). Online consumer retention: contingent effects of online shopping habit and online shopping experience. European Journal of Information Systems 16, 780-792

Kompas.com. (8 September 2017). Sejarah E-Commerce Indonesia: Apa Yang Telah Dan Akan Terjadi? https://www.kompasiana.com/sejarah-e-commerce-indonesia-apa-yang-telahdan-akan-terjadi.

Liao, C., Lin, H. N., Luo, M. M., \& Chea, S. (2017). Factors influencing online shoppers' repurchase intentions: The roles of satisfaction and regret. Information \& Management, 54, 651-668.

Li, H., \& Suomi, R. (2007). Electronic Service Quality: A Transaction Process Based Evaluation Model. Presented at the The European Conference on Information Management and Evaluation, Montpellier, France.

Lin, C., \& Lekhawipat, W. (2014). Factors affecting online repurchase intention. Industrial Management \& Data Systems, 114(4), 597-611.

Liu, T. H. (2012). Effect of E-service Quality on Customer Online Repurchase Intentions. PhD Dissertation, Lynn University.

Saleem, Moh. A., Zahra, S., \& Yaseem, A. (2017). Impact of service quality and trust on repurchase intentions - the case of Pakistan airline industry. Asian Pacific Journal of Marketing and Logistcs, 1-48.

Sanchez-Garcia, I., Pieters, R., Zeelenberg, M., \& Bigne, E. (2012). When satisfied consumers do not return: variety seeking's effect on short- and long-term intentions. Psychology and Marketing, 29(1), 15-24.

Sharma, G. W. J. (2015). The effects of online service quality of e-commerce websites on user satisfaction. The Electronic Library , 33(3), 1-18.

Sullivan, Y. W., \& Kim, D. J. (2018). Assessing the effects of consumers' product evaluations and trust on repurchase intention in e-commerce environment. International Journal of Information Management, 39, 199-219.

Xu, J., Benbasat, I., \& Centefelli, R. T. (2013). Integrating Service Quality with System and Information Quality: An Empirical Test in the E-Service Context. MIS Quartely, 37(3), 777-79.

Zehir, C., \& Narcikara, E. (2016). E-Service Quality and E-Recovery Service Quality: Effects on Value Perceptions and Loyalty Intentions. Procedia - Social and Behavioral Sciences $229,427-443$.

Zeithaml, V. A. (2000). Service Quality, Profitability, and the Economic Worth of Customers: What We Know and What We Need to Learn. Journal of the Academy of Marketing Science, 28(1), 67-85.

Zeithaml, V. A., Bitner M. J., \& Gremler, D. D. (2009). Services Marketing: Integrating Customer Focus Across the Firm. McGraw-Hill/Irwin: New York. 